\title{
Effect of spraying gibberellic acid and caffeic acid on yield and fruit quality of White Banaty (Thompson Seedless) grape cultivar
}

\author{
Ibrahim, R.A ${ }^{1}$, M.M. El-Akad ${ }^{1}$ and M.K. Rizkalla ${ }^{2}$ \\ ${ }^{1}$ Pomology Department, Faculty of Agriculture, Assiut University, Assiut, Egypt. \\ ${ }^{2}$ Viticulture Research Department, Horticulture Research Institute, Agriculture Research Center, Giza, Egypt.
}

\begin{abstract}
This experiment was carried out at the Experimental Orchard of Assiut University, Faculty of Agriculture during two successive seasons 2018 and 2019 on 13 years old grapevines of White Banaty (Thompson Seedless) grape cultivar. The experiment aimed to examine the effect of $\mathrm{GA}_{3}$ at different concentration $(10,20,40 \mathrm{ppm}$ and $10+$ $20+40 \mathrm{ppm})$ and caffeic acid as alternative, safety compound at different concentration (1,2,3 g / litter and $1+$ $2+3 \mathrm{~g} / \mathrm{Litter}$ ) on yield and fruit quality of Thompson Seedless grape cultivar. The obtained results revealed that spraying the clusters with $\mathrm{GA}_{3}$ at $10+20+40 \mathrm{ppm}$ gave the highest values of yield components and increased total acidity $\%$ while it decreased fruit quality. On the other hand, spraying caffeic acid at $2 \mathrm{~g} / \mathrm{Litter}$ at full bloom was effective in improving yield, bunch, berry weight and berry quality.

This study concluded that the beneficial effects of spraying caffeic acid (CA) at $2 \mathrm{~g} / \mathrm{Litter}$ at full bloom as a new alternative compound to improve yield and fruit quality of White Banaty (Thompson Seedless) grape cultivar.
\end{abstract}

Keywords: $\mathrm{GA}_{3}$; Caffeic acid; Thompson Seedless (White Banaty); Grape vine.

\section{Introduction}

Grape (Vitis Vinifera L.) is suggested to be one of the most important fruit crops in the world. In Egypt grapes rank second among fruit crops while citrus being the first. Grape fresh fruits and its products are consider rich source of fiber, vitamins and phenolic compounds which well known for their health beneficial compounds (Dhekny, 2016), White Banaty (Thompson Seedless) grape cultivar become one of the most important tables grapes not only for fresh fruit but also for producing raisins in Egypt. Plant growth substances play a major role in plant growth and development. Gibberellic acid still plays an effective role in enhancing growth and fruit development especially in seedless grape cultivar. It used to increase cluster length, berry size and for thinning bunch berries in seedless grape

\footnotetext{
*Corresponding author: Rashad A. Ibrahim,

Email: rashad 4274@yahoo.com

Received: August 20, 2021; Accepted: October 3, 2021;

Published online: October 14, 2021

C) Published by South Valley University.

This is an open access article licensed under (C)(ㄱ)(2)
}

cultivars (Marzouk and Kassem, 2002; Selim, 2007; Zoffoli et al., 2009). $\mathrm{GA}_{3}$ optimum concentration and date of spraying seemed to be beneficial in grape development and yield of various seedless cultivars (Thomas, 1979). Recently, the natural plant extracts used as a new alternative compounds for improving yield and fruit quality as safety agents for human and environment. Caffeic acid (CA) is a polyphenol produced through the secondary metabolism of vegetables, including olives, coffee beans, fruits, potatoes, carrots and propolis. (Zhang et al., 2014). CA participates in the defence mechanism plants against predators, pests and infections, as it has inhibitory effect on the growth of insects, fungi and bacteria and also promote the protection of plant leaves against ultraviolet radiation $\mathrm{B}$. Application plant extracts improved growth and productivity of fruits crops by regulating plants growth and relieving biotic and abiotic stress was applied by many researchers (Chen and Ho; 1997; Culver et al., 2012; Carreno AL, Alday et al., 2017 ).Our experiment investigates the possibility of using Caffeic 
acid instead of $\mathrm{GA}_{3}$ in grape production to overcome the adverse $\mathrm{GA}_{3}$ effects.

This investigation aimed to examine the effect of spraying caffeic acid (as a new alternative compounds) and $\mathrm{GA}_{3}$ on yield and fruit quality of White Banaty (Thompson Seedless) grape cultivar under Assiut climatic conditions.

\section{Materials and Methods}

This study was carried out during two successive seasons 2018 and 2019 on 13 years old vines of White Banaty (Thompson Seedless) grape cultivar grown at the experimental orchard of Assiut University, Faculty of Agriculture. The selected vines were planted at $2 \times 2.5 \mathrm{~m}$ apart. Twenty-seven uniform grapevines were chosen. All grapevines were pruned as traditional training system with ten (10) fruiting spurs and 6 buds were left on each spur plus 4 renewal spurs with 2 buds (68 eyes/ vine were left) The treatments were as follow:

1- Control (sprayed with water only).

2- Spraying with Gibberellic acid $\left(\mathrm{GA}_{3}\right)$ at $10 \mathrm{ppm}$ when shoot length about 10$15 \mathrm{~cm}$.

3- Spraying with caffeic acid (CA) at 1 $\mathrm{g} /$ Litter when shoot length about 10-15 $\mathrm{cm}$.

4- Spraying with Gibberellic acid $\left(\mathrm{GA}_{3}\right)$ at $20 \mathrm{ppm}$ at full bloom.

5- Spraying with caffeic acid at $2 \mathrm{~g} /$ Litter at full bloom.

6- Spraying with $\mathrm{GA}_{3}$ at $40 \mathrm{ppm}$ when berry volume about $5 \mathrm{~mm}$.

7- Spraying with caffeic acid at $3 \mathrm{~g} /$ Litter when berry volume reached $5 \mathrm{~mm}$.

8- Spraying with $\mathrm{GA}_{3}$ at $10+20+40$ ppm when shoot length about 10-15 $\mathrm{cm}+$ full bloom + berry volume $5 \mathrm{~mm}$.

9- Spraying with caffeic acid at $1+2+3$ $\mathrm{g} /$ Litter when shoot length about 10-15 $\mathrm{cm}+$ full bloom + berry volume $5 \mathrm{~mm}$.

Caffeic acid as extracted from Nescafe Bourders and it's percentage is (33\%) nestle Egypt.
Harvesting was carried out at the normal commercial harvest date at the second week of July during the two studied seasons. The following parameters were estimated for each vine (3 replicates /vine) for each treatment.

\subsection{Yield and cluster characteristics}

1- Yield weight $(\mathrm{kg})$ per grapevine: was recorded at harvest date from average number of cluster per vine and average cluster weight $(\mathrm{g})$.

2- Bunch (cluster) weight (g).

3- Bunch length $(\mathrm{cm})$ and width $(\mathrm{cm})$.

\subsection{Berry physical properties}

Fifty berries per replicate of each treatment were picked randomly and the following measurements were achieved:

1- Fifty (50) berries weight (g).

2- Berry length and diameter $(\mathrm{cm})$.

3- 50 berries juice weight: sample of fifty grape berry were taken for extracting grape juice to determine the average of juice weight.

\subsection{Berry chemical constituents}

The following constituents were estimated in the juice according the corresponding methods:

1- Percentage of total soluble solids in the berry juice was determined by the use of hand refractometer.

2- Percentage of total acidity in the juice was determined by titration with $0.1 \mathrm{~N}$ $\mathrm{NaOH}$ using phenolphthalein as an indicator then the results were calculated as grams of tartaric acid per $100 \mathrm{ml}$ juice.

3- The ratio between the TSS\% and titratable acidity \% (TSS/TA) ratio was calculated.

4- Reducing sugars percentage: was determined according to method of Lane and Eynon outlined in (A.O.A.C., 2000). 
The experiment of this study was conducted in a complete randomized block design (CRBD) with three replicates, one grapevine each.

The obtained results were statistically analyzed according to Snedecor and Cochran (1972). The mean of treatments were compared using the L.S.D. test at level of $5 \%$.

\section{Results}

\subsection{Effect of $\mathrm{GA}_{3}$ and caffeic acid on yield components}

\subsubsection{Yield weight (kg/vine)}

Presented date in Table (1) indicated that all treatments induced significant increase in yield weight $(\mathrm{kg} / \mathrm{vine})$ compared with untreated vines during $2018 \& 2019$ seasons.

According to the obtained results of this study it was found that spraying $\mathrm{GA}_{3}$ at 10 ppm when shoot length about $10-15 \mathrm{~cm}+20$ ppm at full bloom +40 ppm when berry reached $5 \mathrm{~mm}$ caused the heaviest yield weight $(13.667 \& 12.667 \mathrm{~kg} /$ vine$)$ followed by spraying $\mathrm{GA}_{3}$ at $20 \mathrm{ppm}$ at full bloom (13.833 $\& 12.333)$ and caffeic acid at $2 \mathrm{~g} /$ Litter (10.5 $\& 10.33 \mathrm{~kg} / \mathrm{vine})$ while untreated vines gave the lowest yield weight $(6.800 \& 6.866$ $\mathrm{kg} / \mathrm{vine}$ ) during 2018 \& 2019 seasons, respectively.

\subsubsection{Bunch weight (g)}

Data presented in the same table showed that spraying $\mathrm{GA}_{3}$ at $10+30+40 \mathrm{ppm}$ significantly improved bunch weight $(\mathrm{g})$ followed by $\mathrm{GA}_{3}$ at $20 \mathrm{ppm}$ and caffeic acid at $2 \mathrm{~g} /$ Litter. The bunch weight (g) associated with the previous treatments was 485.5, 480 and $362.2 \mathrm{~g}$ as an average of the two studied seasons, respectively. On the other hand, the control vines gave the lowest bunch weight among all treatments (196.4 $\mathrm{g}$ as an average of two seasons).

\subsubsection{Bunch length and width (cm)}

Data presented in Table (1) showed the effect of $\mathrm{GA}_{3}$ and caffeic acid on bunch length and width. According to the obtained results it was found that spraying $\mathrm{GA}_{3}$ at $10+20+40$ ppm gave the highest cluster length and width followed by $\mathrm{GA}_{3}$ at $10 \mathrm{ppm}$ and caffeic acid at $2(\mathrm{~g})$, while the untreated vine gave the lowest values. The average value of cluster length and width associated with these treatments were $(26.08 \& 10.834 \mathrm{~cm}),(24.00 \& 9.917 \mathrm{~cm})$ and (23.83 \& $9.417 \mathrm{~cm})$ comparing with the control $(17.42 \& 6.417 \mathrm{~cm})$ as an average of the two studied seasons.

\subsection{Berry physical characteristics}

Data recorded in Table (2) showed the effect of spraying $\mathrm{GA}_{3}$ and caffeic acid on berry physical characteristics.

\subsubsection{Berry height and diameter (cm)}

The obtained results revealed that all treatments induced a significant increase in berry height and diameter $(\mathrm{cm})$ compared with untreated vines during 2018 and 2019 seasons.

The previous results showed that spraying $\mathrm{GA}_{3}$ at $(10+20+40 \mathrm{ppm})$ followed by spraying $\mathrm{GA}_{3}$ at $20 \mathrm{ppm}$ and caffeic acid at 2 (g/Litter) had the highest berry height and diameter $(\mathrm{cm})$ while the control vines had the lowest berry height and diameter during the two studied seasons.

The average values of berry height and diameter $(\mathrm{cm})$ associated with these three treatments were $(2.050 \& 1.584 \mathrm{~cm}),(1.934 \&$ $1.417 \mathrm{~cm})$ and $(1.667 \& 1.367 \mathrm{~cm})$ as an average of two seasons, respectively. The control vine gave the lowest berry height $(1.317 \mathrm{~cm})$ and diameter $(1.033 \mathrm{~cm})$ as an average of the two studied seasons.

\subsubsection{Weight of 50 berry (g) and 50 berry juice weight (g)}

As shown in Table (2) it could be noticed that spraying $\mathrm{GA}_{3}$ at $(10+20+40 \mathrm{ppm}), \mathrm{GA}_{3}$ at 20 ppm and caffeic acid at $2 \mathrm{~g} /$ Litter) significantly increased both of 50 berry weight $(\mathrm{g})$ and 50 berry juice weight $(\mathrm{g})$. The recorded values of 50 berry weight and 50 berry juice weight for 
such treatments were $(145 \& 93.14 \mathrm{~g}),(105 \&$ $65.81 \mathrm{~g})$ and $(80.84 \& 53.53 \mathrm{~g})$ comparing with the control treatment $(54.17 \& 35.29 \mathrm{~g})$ as an average of 2018 and 2019 seasons. 
Table 1. Effect of Gibberellic acid and caffeic acid on yield (kg), bunch weight (g) and dimensions (cm) of White Banaty (Thompson Seedless) grape cultivar during 2018 and 2019 seasons.

\begin{tabular}{|c|c|c|c|c|c|c|c|c|c|c|c|c|}
\hline \multirow{2}{*}{ Treatments } & \multicolumn{3}{|c|}{ Yield weight $(\mathrm{Kg})$} & \multicolumn{3}{|c|}{ Bunch weight (g) } & \multicolumn{3}{|c|}{ Bunch Length $(\mathrm{cm})$} & \multicolumn{3}{|c|}{ Bunch Width $(\mathrm{cm})$} \\
\hline & 2018 & 2019 & Mean & 2018 & 2019 & Mean & 2018 & 2019 & Mean & 2018 & 2019 & Mean \\
\hline Control & 6.800 & 6.866 & 6.833 & 195.0 & 197.7 & 196.4 & 17.83 & 17.00 & 17.42 & 4.833 & 8.000 & 6.417 \\
\hline $\mathrm{GA}_{3} 10 \mathrm{ppm}$ & 9.000 & 9.500 & 9.250 & 248.3 & 320.0 & 284.2 & 27.33 & 20.67 & 24.00 & 9.667 & 10.167 & 9.917 \\
\hline Caffeic acid ( $1 \mathrm{~g} /$ Litter $)$ & 8.667 & 9.167 & 8.917 & 223.3 & 278.3 & 250.8 & 23.00 & 21.67 & 22.34 & 5.667 & 10.000 & 7.834 \\
\hline $\mathrm{GA}_{3} 20 \mathrm{ppm}$ & 13.833 & 12.333 & 13.083 & 520.0 & 440.0 & 480.0 & 21.00 & 23.00 & 22.00 & 9.333 & 9.333 & 9.333 \\
\hline Caffeic acid ( $2 \mathrm{~g} /$ Litter $)$ & 10.500 & 10.333 & 10.417 & 379.3 & 345.0 & 362.2 & 20.33 & 27.33 & 23.83 & 8.167 & 10.667 & 9.417 \\
\hline $\mathrm{GA}_{3} 40 \mathrm{ppm}$ & 10.167 & 10.500 & 10.334 & 340.0 & 372.0 & 356.0 & 21.50 & 20.00 & 20.75 & 6.667 & 10.667 & 8.667 \\
\hline Caffeic acid ( $3 \mathrm{~g} /$ Litter) & 9.167 & 10.333 & 9.750 & 253.3 & 327.3 & 290.3 & 16.17 & 19.33 & 17.75 & 6.667 & 9.000 & 7.834 \\
\hline $\mathrm{GA}_{3} 10+20+40 \mathrm{ppm}$ & 13.667 & 12.667 & 13.167 & 536.0 & 435.0 & 485.5 & 28.83 & 23.33 & 26.08 & 10.667 & 11.000 & 10.834 \\
\hline Caffeic acid $(1+2+3 \mathrm{~g})$ & 8.833 & 9.167 & 9.000 & 251.7 & 271.7 & 261.7 & 19.83 & 21.67 & 20.75 & 7.500 & 9.333 & 8.417 \\
\hline New L.S.D 0.05 & 0.873 & 0.870 & & 12.86 & 14.29 & & 1.918 & 2.215 & & 1.236 & 1.708 & \\
\hline
\end{tabular}


Table 2. Effect of Gibberellic acid and caffeic acid on berries weight (g), berries juice weight (g) and berry dimensions (cm) of White Banaty (Thompson Seedless) grape cultivar during 2018 and 2019 seasons.

\begin{tabular}{|c|c|c|c|c|c|c|c|c|c|c|c|c|}
\hline \multirow{2}{*}{ Treatments } & \multicolumn{3}{|c|}{ Berry length(cm) } & \multicolumn{3}{|c|}{ Berry diameter $(\mathrm{cm})$} & \multicolumn{3}{|c|}{50 berries weight $(\mathrm{g})$} & \multicolumn{3}{|c|}{50 berries Juice weight $(\mathrm{g})$} \\
\hline & 2018 & 2019 & mean & 2018 & 2019 & Mean & 2018 & 2019 & mean & 2018 & 2019 & mean \\
\hline Control & 1.367 & 1.267 & 1.317 & 1.033 & 1.033 & 1.033 & 56.67 & 51.67 & 54.17 & 36.83 & 33.75 & 35.29 \\
\hline $\mathrm{GA}_{3} 10 \mathrm{ppm}$ & 1.467 & 1.433 & 1.450 & 1.233 & 1.267 & 1.250 & 61.67 & 58.33 & 60.00 & 42.15 & 39.03 & 40.59 \\
\hline Caffeic acid (1 g/litter) & 1.533 & 1.467 & 1.500 & 1.267 & 1.200 & 1.234 & 61.67 & 71.67 & 66.67 & 44.07 & 50.00 & 47.04 \\
\hline $\mathrm{GA}_{3} 20 \mathrm{ppm}$ & 2.067 & 1.800 & 1.934 & 1.467 & 1.367 & 1.417 & 123.33 & 86.67 & 105.0 & 73.44 & 58.17 & 65.81 \\
\hline Caffeic acid (2 g/litter) & 1.733 & 1.600 & 1.667 & 1.433 & 1.300 & 1.367 & 91.67 & 70.00 & 80.84 & 58.83 & 48.23 & 53.53 \\
\hline $\mathrm{GA}_{3} 40 \mathrm{ppm}$ & 1.667 & 1.567 & 1.617 & 1.367 & 1.333 & 1.350 & 80.00 & 71.67 & 75.84 & 45.02 & 44.70 & 44.86 \\
\hline Caffeic acid (3 g/litter) & 1.533 & 1.500 & 1.517 & 1.267 & 1.167 & 1.217 & 58.33 & 65.00 & 61.67 & 36.70 & 41.57 & 39.14 \\
\hline $\mathrm{GA}_{3} 10+20+40 \mathrm{ppm}$ & 2.033 & 2.067 & 2.050 & 1.600 & 1.567 & 1.584 & 158.33 & 131.67 & 145.00 & 97.78 & 88.50 & 93.14 \\
\hline Caffeic acid $(1+2+3 \mathrm{~g})$ & 1.500 & 1.567 & 1.534 & 1.233 & 1.300 & 1.267 & 66.67 & 65.00 & 65.84 & 38.70 & 40.23 & 39.47 \\
\hline New L.S.D 0.05 & 0.109 & 0.133 & & 0.108 & 0.132 & & 10.18 & 9.48 & & 6.108 & 3.55 & \\
\hline
\end{tabular}




\subsection{Berry chemical constituents}

\subsubsection{Total soluble solids percentage (TSS\%)}

Presented data in Table (3) indicated that spraying caffeic acid at $2(\mathrm{~g})$ and caffeic acid at $(1+2+3 \mathrm{~g})$ induced significant increase in (TSS\%) in berry juice of White Banaty (Thompson Seedless) grape cultivar. It was observed that spraying caffeic acid at $2(\mathrm{~g})$ resulted the highest TSS\% (22.14\%) followed by spraying caffeic acid at $(1+2+3 \mathrm{~g})$ (21.73\%) on the other hand the lowest TSS\% values were obtained from spraying $\mathrm{GA}_{3}$ at different concentrations as an average of 2018 and 2019 seasons.

\subsubsection{Total acidity (TA\%) and TSS/TA ratio}

Data illustrated in Table (3) showed that spraying $\mathrm{GA}_{3}$ at $(10,20,40$ and $10+20+40$ $\mathrm{ppm})$ increased TA\% compared with the other treatments. $\mathrm{GA}_{3}$ at $(10+20+40 \mathrm{ppm})$ gave the highest values $(0.588 \%)$ followed by $\mathrm{GA}_{3}$ at $20 \mathrm{ppm}(0.578 \%)$ on the other hand spraying caffeic acid at different concentrations had the lowest TA\% values. Spraying caffeic acid at 1 (g) gave the lowest values $(0.422 \%)$ as an average of the two studied seasons. $\mathrm{GA}_{3}$ spraying recorded also the least TSS/TA ratio however caffeic acid treatments significantly increased it in this respect. The TSS/TA ratio were $51.25,49.59$ and 49.34 for caffeic acid at $(1+2+3 \mathrm{~g} /$ Litter $)$, caffeic acid at $2(\mathrm{~g})$ and caffeic acid at $(1 \mathrm{~g})$ respectively, as an average of 2018 and 2019 seasons. While, the lowest TSS/TA values were (32.6, 35.42 and 37.06) for $\mathrm{GA}_{3}$ at $(10+20+40 \mathrm{ppm}, 20 \mathrm{ppm}$ and 40 ppm) as an average of the two studied seasons.

\subsubsection{Reducing sugars $\%$}

Concerning the effect of spraying $\mathrm{GA}_{3}$ and caffeic acid at different concentrations on reducing sugars $\%$ of White Banaty grape cultivar. The recorded data of reducing sugars $\%$ showed that spraying caffeic acid at 2
g/Litter gave the highest values (18.26\%) followed by caffeic acid at $(1+2+3 \mathrm{~g})$ $(17.59 \%)$ while spraying $\mathrm{GA}_{3}$ at $(10+20+40$ $\mathrm{ppm})$ had the lowest values $(14.95 \%)$ as an average of 2018 and 2019 seasons.

\section{Discussion and Conclusion}

Many researchers reported that using $\mathrm{GA}_{3}$ on different grape cultivars increase yield, cluster weight, length, width and berry size while it decreased berry quality (TSS\% and sugars contents) (Hussein et al., 1986; Hassan et al., 1988; Rizk-Alla et al., 2011). On the other hand, the obtained results came in the same line with these reported by Mansour (1994), Abd El-Ghany (2000) and El-Akad et al. (2021) who found that spraying seedless grape cultivars with $\mathrm{GA}_{3}$ increased yield, cluster weight, length and berry weight while it decreased TSS\%, sugars and increased acidity $\%$.

Recently, researchers used natural plant extracts to improve growth and productivity of fruit crops by regulating plant growth and relieving biotic and abiotic stresses (Mostafa et al., 2015; Ahmed et al., 2017; El-Kenawy, 2018; El-Salhy et al., 2017). Caffeic acid is widely distributed in nature and possesses strong antioxidant activity (Wang et al., 2014). Zhange et al. (2014) evaluated the effects of different concentrations of caffeic acid on maintenance of post-harvest fruit quality and to extend the shelf life of mulberry fruit. The results of the current study showed that caffeic acid increased yield, cluster weight and improved berry weight of White Banaty (Thompson Seedless) grape cultivar. These obtained results could be attributed to CA participates in the defence mechanism plants against predators, pests and infections, as it has inhibitory effect on the growth of insects, fungi and bacteria and also promote the protection of plant leaves against ultraviolet radiation B, regulating plants growth and relieving biotic and abiotic stress (Chen and Ho; 1997; Culver et al., 2012; Carreno AL, Alday et al., 2017) 
Table 3. Effect of Gibberellic acid and caffeic acid on TSS\%, TA\%, TSS/TA ratio and reducing sugars \% of White Banaty (Thompson Seedless) grape cultivar during 2018 and 2019 seasons.

\begin{tabular}{|c|c|c|c|c|c|c|c|c|c|c|c|c|}
\hline \multirow{2}{*}{ Treatments } & \multicolumn{3}{|c|}{ T.S.S \% } & \multicolumn{3}{|c|}{ TA \% } & \multicolumn{3}{|c|}{ TSS/TA ratio } & \multicolumn{3}{|c|}{ Reducing sugars $\%$} \\
\hline & 2018 & 2019 & mean & 2018 & 2019 & Mean & 2018 & 2019 & mean & 2018 & 2019 & mean \\
\hline Control & 21.63 & 20.37 & 21.00 & 0.480 & 0.513 & 0.497 & 45.06 & 39.71 & 42.39 & 18.78 & 14.38 & 16.58 \\
\hline $\mathrm{GA}_{3} 10 \mathrm{ppm}$ & 21.50 & 19.60 & 20.55 & 0.513 & 0.550 & 0.532 & 41.91 & 35.64 & 38.63 & 16.83 & 15.56 & 16.20 \\
\hline Caffeic acid ( $1 \mathrm{~g} /$ Litter $)$ & 22.33 & 19.30 & 20.82 & 0.423 & 0.420 & 0.422 & 52.79 & 46.04 & 49.34 & 17.83 & 15.77 & 16.80 \\
\hline $\mathrm{GA}_{3} 20 \mathrm{ppm}$ & 21.73 & 19.20 & 20.47 & 0.563 & 0.593 & 0.578 & 38.6 & 32.37 & 35.42 & 17.77 & 14.91 & 16.34 \\
\hline Caffeic acid (2 g/Litter) & 22.07 & 22.20 & 22.14 & 0.453 & 0.440 & 0.447 & 48.71 & 50.46 & 49.59 & 18.73 & 17.79 & 18.26 \\
\hline $\mathrm{GA}_{3} 40 \mathrm{ppm}$ & 21.07 & 18.50 & 19.79 & 0.510 & 0.557 & 0.534 & 41.31 & 33.25 & 37.06 & 16.90 & 13.85 & 15.38 \\
\hline Caffeic acid ( $3 \mathrm{~g} /$ Litter) & 22.07 & 19.27 & 20.67 & 0.470 & 0.460 & 0.465 & 46.96 & 41.94 & 44.45 & 18.29 & 14.28 & 16.29 \\
\hline $\mathrm{GA}_{3} 10+20+40 \mathrm{ppm}$ & 20.13 & 18.20 & 19.17 & 0.573 & 0.603 & 0.588 & 35.13 & 30.18 & 32.6 & 16.41 & 13.48 & 14.95 \\
\hline Caffeic acid $(1+2+3 \mathrm{~g})$ & 22.13 & 21.33 & 21.73 & 0.407 & 0.440 & 0.424 & 54.37 & 48.57 & 51.25 & 18.61 & 16.56 & 17.59 \\
\hline New L.S.D 0.05 & 0.326 & 0.372 & & 0.054 & 0.017 & & 4.532 & 3.011 & & 0.543 & 0.74 & \\
\hline
\end{tabular}


and to an estimulative effect of caffeic acid in enhancement of biosynthesis of IAA in cells of the grape berries resulted in more cell elongation (Kefeli and Kutacek, 1976). The obtained results showed a positive effect of caffeic acid on improving berries quality such as increasing TSS\%, reducing sugars and reducing TA\% of white banaty berries juice this may be due to the continued biosynthesis of phenolic acid compounds and it is related to the ripening processes (Wang and Gao, 2013).

\section{Recommendation}

According to the obtained results under the conditions of our study it could be recommended that spraying caffeic acid at 2 $\mathrm{g} /$ Litter at full bloom as a new alternative compound for improve yield and fruit quality of White Banaty (Thompson Seedless) grape cultivar.

\section{References}

Abd El-Ghany, A.A. (2000) 'Effect of shoot topping, paclobotrazol and gibberellic acid application on fruit quality of Thompson Seedless grapevines' Assiut Journal of Agricultural Sciences, 31 (2): pp. 49-57.

Ahmed, A.M.K., Abd, M.A.M. and Mohamed, H.A.E. (2017) 'Trials for solving the problem of poor berries colouration and improving yield of Crimson Seedless grapevines' New York Science Journal, 10 (12): pp. 91-103.

Association Official Agricultural Chemist (A.O.A.C.) (2000) 'Official Methods of Analysis $(A O A C)$ ' $12^{\text {th }} \mathrm{Ed}$, Benjamin Franklin Station, Washington DC, USA, pp. 490-510.

Carreno AL, Alday E., Quintero, J., Perez, L., Valencia, D., Robles-Zepeda, R., Valdez-Ortega, J., Hernandez, J. and Velazquez Carlos (2017) 'Protective effect of caffeic acid phenethyl ester (CAPE) against oxidative stress' Journal of Functional Foods, 29: pp. 178-184.
Chen, J.H. and Ho, C.T. (1997) 'Antioxidant activities of caffeic acid and its related hydroxy-cinnamic acid compounds' $J$ Agric Food Chem., 45:2374-8.doi: 10.1021/jf970055t

Culver, M., Fanuel T. and Chiteka, A.Z. (2012) 'Effect of moringa extract on growth and yield of tomato' Greener J. Agric. Sci., 2207-2211.

Dhekny, S.A. (2016) 'Encyclopedia of food and health.' Academic Press, Oxford, pp. 261-265.

El-Akad, M.M., Rizkalla, M.K. and Ibrahim, R.A. (2021) 'Effect of gibberellic acid and jasmine oil on yield and fruit quality of Ruby Seedless grape cultivar' SVU-International Journal of Agricultural Science, Volume 3 Issue 1, pp: 85-95.

El-Kenawy, M.A. (2018) 'Effect of spraying jasmonic acid, girdling and their combinations on growth, yield and fruit quality of Crimson Seedless grapevine' Egypt. J. Hort., 45 (1): pp. 25-37.

El-Salhy, A.M., Ibrahim, R.A., Mgawer, M.A. and Abd El-Hafiz, G.N. (2017) 'Effect of some plant extracts spraying on growth and fruiting of Flame Seedless grapevines' Assiut J. of Agric. Sci., 48 (3): pp. 188-197.

Hassan, J.A., Mohamad, A.A., Al-Ameeli, Z.M. and Hadi, B.S. (1988) 'Effect of gibberelic acid yield and fruit quality of Perlette grape cultivar (Vitis vinifera L.)' Annals Agric. Sci., Fac. Agric., Ain Shams Univ., Cairo, Egypt, 33 (1): pp. 471-478.

Hussein, A.A.M., Abdel-Hameed, N.M.G., Nour, G.M. and Moustafa, A.A. (1986) 'Response of "Roumi Red" grapevines to applications of CCC and $\mathrm{GA}_{3}$ ' Annals Agric. Sci., Fac. Agric., Ain Shams Univ., Cairo, Egypt, 31 (1): pp. 637-650. 
Kefeli, V. and Kutacek, M. (1976) 'Producing in life science, ed' Pilot RE, SpringerVerlag, Berlin, pp. 18.

Mansour, A.E.M. (1994) 'Application of gibberellic acid and cycocel on berries development and productivity of Thompson Seedless grapevines' Minia J. Agric. Res. \& Dev., Vol. 16: pp. 323-334.

Marzouk, H.A. and Kassem, H.A. (2002) 'Yield and fruit quality at harvest or after storage of Flame Seedless grape as affected by frequent sprays of Gibberellic acid' J. Adv. Agric. Res., Alexandria Univ., 7 (3): pp. 525-537.

Mostafa, F.M., Mohamed, A.K.A., MervatAly, A. and Rizkalla, M.K. (2015) 'Effect of garlic and camphor oils on bud fertility and yield components of Flame Seedless grape cultivar' Assiut J. Agric. Sci., 46 (3): pp.100-119.

RizkAlla, M.S., Abd El-Wahab, M.A. and Fekry, O.M. (2011) 'Application of $\mathrm{GA}_{3}$ and NAA as a means for improving yield, fruit quality and storability of Black Monukka grape cv' Nature and Science, 9 (1): pp.1-19.

Selim, A.A. (2007) 'Response of Flame Seedless grapes to some improving treatments under Assiut environments' M.Sc. Thesis, Fac. Agric., Assiut Univ., Egypt.
Snedecor, G.W. and Cochran, W.G. (1972) 'Statistical Methods' Iowa State University, Ames, USA

Thomas, C.M. (1979) 'Biochemistry and physiology of plant hormones' Published by Springer Verlage, Inc. New York, pp. 90-142.

Wang, J., Gu, S.S., Pang, N., Wang, F.Q., Pang, F., Cu, H.S., Wu, X.Y. and Wu, F.A. (2014) 'Alkyl caffeates improve the antioxidant activity, antitumor property and oxidation stability of edible oil' Plos One, 9 (4) e 95909.

Wang, S.Y. and Gao, H. (2013) 'Effect of chistosan-based edible coating on antioxidants enzyme system and postharvest fruit quality of strawberries (Fragaria $x$ aranassa Duch)' Lebensmittel Wissenchaft Und Technologie 52 (2): pp. 71-79.

Zhang, P., Tang, Y., Li, N.G., Zhu, Y. and Duan, J.A. (2014) 'Bioactivity and chemical synthesis of caffeic acid phenethyl ester and its derivativers' Molecules 19 (10): pp. 16458-16476.

Zoffoli, J.P., Latorre, B.A. and Naranj, P. (2009) 'Pre-harvest application of growth regulators and their effect on post-harvest quality of table grape during cold storage' Post-harvest Biology and Technology, 51 (2): pp. 183-192. 